Hasanatul Rahmi, JumiatilImplementasi Kebijakan Ketahanan Pangan dalam Meningkatkan Kesejahteraan Masyarakat di Kabupaten Pesisir Selatan (Studi Kasus Pengelolaan Cadangan Pangan Masyarakat)

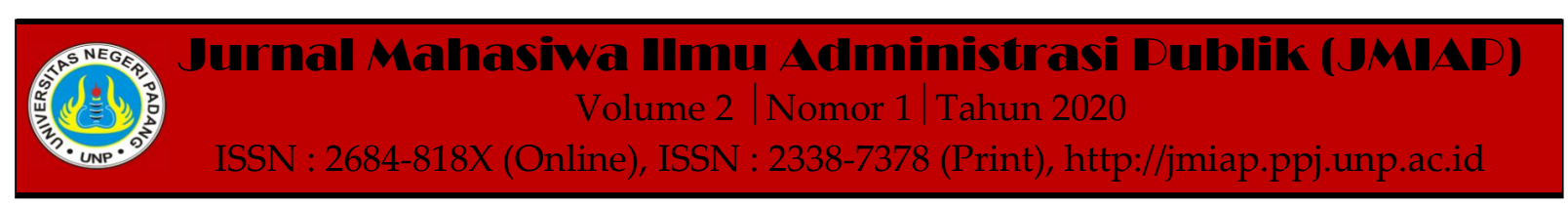

\title{
IMPLEMENTASI KEBIJAKAN KETAHANAN PANGAN DALAM MENINGKATKAN KESEJAHTERAAN MASYARAKAT DI KABUPATEN PESISIR SELATAN (Studi Kasus Pengelolaan Cadangan Pangan Masyarakat)
}

\author{
Hasanatul Rahmi ${ }^{1(a)}$, Jumiati ${ }^{2(b)}$ \\ ${ }^{1}$ Jurusan Ilmu Administrasi Negara, Universitas Negeri Padang \\ ${ }^{2}$ Jurusan Ilmu Administrasi Negara, Universitas Negeri Padang \\ a)hasanatulrahmi29@gmail.com, b)jumiati.upik1962@gmail.com
}

\begin{abstract}
The purpose of this study is to find out the implementation of food security policies to improve welfare through food reserve management programs. The aim is to increase the volume of group food reserves to ensure access and adequate food for its members and increase group capital through productive economic endeavors. This study uses qualitative research with a normativeempirical and phenomenal approach. The informants in this study were determined by purposive sampling with a total of 4 people, namely the Head of Planning, the Head of Food Security, the Mayor of Nagari and the Community. The data used are primary data and secondary data, derived from field observations or observations, interviews and documentation studies. This data is tested for validity using source triangulation techniques which are then analyzed with qualitative data analysis techniques. The results showed that the process of implementing food security policy in its implementation still needed some improvements such as in terms of resources involved, characteristics of the ruling institutions and responses from implementers. Supporting factors in the implementation of food security policies are built by the government food storage (granary) which is built by the special allocation fund (DAK) in agriculture and is given a budget in replenishing community food reserves. Whereas the saving factor is the lack of community understanding of how the system in managing community food reserves which causes internal problems in groups such as people who borrow grain / rice in storage (granaries) do not return loans according to the agreement. Efforts made by the Department of Food directly met with members of the group to request that loans be returned in accordance with the agreement that had been made so that the stock of community food reserves could still be available in storage areas (granaries).
\end{abstract}

Keywords : Implementation of Food Security Policies, Public Welfare, Food Reserve Management

Corresponding author. Email.hasanatulrahmi29@gmail.com, jumiati.upik1962@gmail.com

How to cite this article. Rahmi, H \& Jumiati. (2020). Implementasi Kebijakan Ketahanan Pangan dalam Meningkatkan Kesejahteraan Masyarakat di Kabupaten Pesisir Selatan (Studi Kasus Pengelolaan Cadangan Pangan Masyarakat). Jurnal Mahasiwa Ilmu Administrasi Publik (JMIAP) Jurusan Ilmu Administrasi Negara Fakultas Ilmu Sosial Universitas Negeri Padang, Volume 2 (1), Hal. 12-23.

http://jmiap.ppj.unp.ac.id

ISSN : 2684-818X (Online), ISSN : 2338-7378 (Print)

Copyright $\bigcirc 2020$. Published by Pusat Kajian-Pemberdayaan dan Pelayanan Masyarakat (PK-P2M) FIS UNP Padang 


\section{PENDAHULUAN}

Kondisi terpenuhinya pangan bagi negara sampai dengan perorangan yang dapat tercermin dari tercukupinya ketersediaan pangan baik jumlah maupun mutunya, aman, beragam, bergisizi, merata serta terjangkau dan tidak bertentangan dengan agama, keyakinan dan budaya masyarakat, untuk dapat hidup sehat, aktif, dan produktif secara berkelanjutan (Undang-Undang Nomor 18 tahun 2012 tentang Pangan). Tidak tersedianya pangan dalam jumlah yang cukup serta mutu yang memadai dapat diartikan sebagai tidak sejahteranya kehidupan dan terjadinya kemiskinan.

Dalam upaya menekan angka kemiskinan, berpedoman kepada (UndangUndang Nomor 18 tahun 2012 tentang Pangan )menyatakan bahwa pemerintah dan pemerintah daerah melaksanakan kebijakan dan bertanggung jawab terhadap penyelenggaraan ketahanan pengan diwilayahnya masing-masing dengan memperhatikan pedoman, norma, standard dan kriteria yang ditetapkan Pemerintah Pusat. Pemerintahan daerah dan pemerintahan nagari diikut sertakan sebagai pendorong keiukutsertaan masyarakat dalam penyelenggaraan ketahanan pangan. Selain itu ketahanan pangan juga diatur lebih lanjut di dalam peraturan pemerintah republik Indonesia Nomor 17 Tahun 2015 tentang Ketahanan Pangan dan gizi.

Dalam rangka menciptakan ketahanan pangan untuk meningkatkan kesejahteraan masyarakat, Pemerintah Kabupaten Pesisir Selatan melalui Dinas Pangan telah berupaya dalam meningkatkan ketahanan pangan daerah melalui implementasi kebijakan ketahanan melalui cadangan pangan masyarakat dengan melakukan pemberdayaan masyarakat untuk dapat mengelola cadangan pangan mereka sendiri, mempercepat penganekaragaman konsumsi pangan pangan, membentuk dewan ketahanan pangan dan pengembangan desa mandiri pangan.
Disini peneliti lebih memfokuskan penciptaan ketahanan pangan dengan implementasi kebijakan ketahanan pangan melalui sistem pengelolaan cadangan pangan masyarakat dilakukuan dengan dalam rangka pemberdayaan dan perlindungan masyarakat dari kerawanan pangan, dengan memfasilitasi pembangunan fisik lumbung, pengisian cadangan pangan dan penguatan lembaga kelompok.

Untuk cadangan pangan masyarakat melalui program pengembangan lumpung pangan adanya (Peraturan Pemerintah No.68 tahun 2002 tentang Ketahanan Pangan pasal 8)menjelaskan bahwa : "masyarakat mempunyai hak dan kesempatan seluas-luasnya dalam mewujudkan cadangan pangan masayrakat yang dilakukan secara mandiri serta sesuai dengan kemampuan masing-masing”. Selanjutnya pasal pasal 14 menegaskan bahwa "masyarakat memilki kesempatan yang seluas-luasnya dalam mewujudkan ketahanan pangan, dimana peran masyarakat dapat berupa : a. Melaksanakan produksi, perdagangan, distribusi dan konsumsi pangan, b. Menyelenggarakan cadangan pangan masyarakat dan, c. Melakukan pencegahan dan penanggulangan serangan hama dan penyakit, banjir dll.

Cadangan pangan masyarakat melalui kelembagaan lumbung pangan ada beberapa tahapan, yaitu tahap penumbuhan, tahap pengembangan dan tahap kemandirian. Pada tahap penumbuhan kegiatan yang dilakukan adalah idintivikasi kelompok, pemberiaan sosialisasi, seleksi kemudian jika kelompok lulus dalam seleksi maka akan ditetapakan dana untuk pembangunan fisik tempat penyimpanan (lumbung pangan) bagi anggota kelompok. Kemudian pada tahap pengembangan kegiatan yang dilakukan adalah verivikasi, pemberian sosialisasi kegiatan usaha, pemberiaan pelatihan bagi anggota, penyusunan rencana kegiatan usaha, penyaluran dana BANSOS kemudian 
pengisian cadangan pangan serta penguatan kelembagaan dan stok cadangan pangan masyarakat. Dan pada tahap kemandirian, anggota masih dibantu dengan dana BANSOS,penguatan kelembagaan lumbung pangan anggota dan penguatan cadangan pangan anggota serta pemberiaan pelatihan kepada anggota kelompok dalam menunjang keberlanjutan program cadangan pangan dan usaha ekonomi produktif anggota dengan diberikan pendampingan.

Namun dalam realitanya implementasi kebijakan ketahanan pangan melalui pengelolaan cadangan pangan masyarakat dalam penguatan kelembagaan di kabupaten pesisir selatan tidak berjalan dengan baik dan tidak mampu menyediakan kebutuhan akan kemudahan akses pangan bagi anggota kelompok. Karena beberapa cadangan pangan masyarakat melalaui kelembagaan lumbung pangan ada beberapa lumbung pangan yang sudah tidak aktif lagi.(Suryati, 2014).

Dalam kontek pembangunan implementasi kebijakan ketahanan pangan melalui cadangan pangan masyarakat merupakan bagian dari kebijaka publik. Namun kebijakan yang sudah berjalan dari beberapa tahun belakangan belum mampu menunjukkan adanya tingkat ketersedian pangan bagi masyarakat petani dan mencukupi konsumsi pangan. Hal ini dikarenakan kurangnya pemahaman anggota dalam pengelolaan cadangan pangan dan penegembangan usaha ekonomi produktif yang dijalankan, yang mengakibatkan terjadinya permasalahankurang pahamnya anngota kelompok dengan sistem peminjaman bahan pangan yang dapat dipinjamkan kepada anggota, yang mengakibatkan banyak anggota yang tidak mengembalikan pinjaman sesuai dengan kesepakatan yang telah ditentukan. Jika pinjaman tidak dikembalikan akan mengakibatkan stok cadangan pangan anggota pun menipis.(Suryati, 2014).
Pengisian stok cadangan pangan masyarakat telah di anggarkan oleh pemerintah, untuk pengisiain gabah/beras yang nantinya kelompoklah yang akan mengembangkan secara mandiri stok pangan tersebut agar terciptanya usaha ekonomi produktif untuk penambahan pendapatan anggota kelompok. Jika tidak terjadianya perkembangan dalam pengelolaan cadangan pangan masayrakat tersebut maka tidak akantercapainya kemudahan dan ketersediaan akan pangan secara berkelanjutan bagi anggota kelompok.Setelah anggaran diturunkan kelembagaan diberikan wewenang untuk dapat mengembangkan cadangan pangan mereka sendiri dan pengembangan usaha ekonomi produktif kelompok agar terpenuhinya ketersediaan pangan bagi anggota kelompok dan peningkatan modal kelompok.Berdasarkan permasalahan inilah penulis merumuskan masalah sebagai berikut : Pertama bagaimana implementasi kebijakan ketahanan pangan untuk meningkatkan kesejahteraan masyarakat di Kabupaten Pesisir Selatan (pengelolaan cadangan pangan masyarakat). kedua, Apa faktor pendukung dan penghambat dari implementasi kebijakan ketahanan pangan untuk meningkatkan kesejahteraan masyarakat di Kabupaten Pesisir Selatan (pengelolaan cadangan pangan masyarakat). ketiga, Bagaimana upaya pemerintah untuk mengatasi kendala untuk meningkatkan kesejahteraan masyarakat di Kabupaten Pesisir Selatan (pengelolaan cadangan pangan masyarakat).

\section{TINJAUAN PUSTAKA}

\section{Konsep Implementasi Kebijakan}

Implementasi berasal dari bahasa inggris yaitu to implement yang berarti mengimplementasikan.Implementasi pada kamus Webster's dalam (Wahab, 2014) pengertian implementasi dirumuskan secara pendek bahwa "to implement" (mengimplementasikan) berarti " to provide means for carrying out (menyediakan sarana untuk melaksanakan sesuatu) to give 
practical effect to" (menimbulkan dampak/akibat terhadapsesuatu). Implementasi merupakan tindakan yang dilakukan setelah kebijakan publik ditetapkan, untuk mencapai tujuan apataupun sasaran yang ingin dicapai.

\section{Model Merilee S. Grindle}

Model Grindle dikenal dengan "Implementation As A Political and Administrative Process". Grindle (1980) dalam (Haeder 2008:7) menyatakan bahwa keberhasilan suatu kebijakan publik diukur dari proses pencapaian hasil akhir, yaitu tercapai atau tidaknya tujuan yang ingin diraih. Grindle juga mengemukakan bahwa implementasi dipengaruhi oleh dua variabel besar, yakni isi kebijakan dan lingkungan implementasi, kedua hal tersebut harus didukung oleh program aksi dan proyek individu yang didesain dan dibiayai berdasarkan tujuan kebijakan.

1. Variabel isi kebijakan

a) Kepentingan-kepentingan kelompok sasaran. Berkaitan dengan berbagai kepentingan yang mempengaruhi implementasi kebijakan Indikator ini berargumen bahwa suatu kebijakan dalam pelaksanaannya melibatkan banyak kepentingan, dan sejauh mana kepentingan-kepentingan itu berpengaruh terhadap kelompok sasaran.

b) Tipe manfaat. Yaitu jenis manfaat apa yang diterima oleh kelompok sasaran. Manfaat kebijakan ini mempunyai maksud untuk menjelaskan bahwa di dalam sebuah kebijakan, terdapat manfaat yang diperoleh kelompok sasaran saat implementasi kebijakan.

c) Derajat perubahan yang diinginkan. Yakni sejauh mana perubahan yang diinginkan dengan adanya suatu kebijakan, derajat perubahan menunjukkan seberapa besar perubahan yang hendak dicapai dengan adanya kebijakan tersebut.

d) Pelaksana program. Yakni siapa aktor pelaksana implementasi kebijakan, dalam melaksanakan suatu kebijakan harus didukung dengan adanya pelaksana yang memiliki kompetensi dan kualitas yang baik.

e) Sumberdaya yang dilibatkan. Sumber daya yang dilibatkan menjadi tolak ukur keberhasilan suatu implementasi, karena dengan sumberdaya yang berkualitas, implementasi akan bejalan dengan baik.

2. Variabel lingkungan

a) Seberapa besar kekuasaan, kepentingan, dan strategi yang dimiliki oleh para aktor yang terlibat dalam implementasi kebijakan. Hal ini berkaitan dengan proses implementasi, suatu kebijakan perlu diperhitungkan kekuasaan, kepentingan, dan strategi yang dimiliki guna kelancaran implementasi.

b) Karakteristik lembaga penguasa. Yakni bagaimana keberadaan lembaga dimana lingkungan tempat kebijakan tersebut diimplementasikan.

c) Tingkat kepatuhan dan adanya respon dari pelaksana. Yaitu sejauh mana kelompok sasaran mematuhi kebijakan tersebut dan bagaimana respon pelaksana menanggapi kebijakan tersebut.

d) Konsep Ketahanan Pangan. Karsin (2004) dalam (Supriyanto, 2014:9),pangan merupakan kebutuhan dasar yang paling esensial bagi manusianuntuk mempertahankan hidup dan kehidupan. Pangan sebagai sumber zat gizi(karbohidrat, lemak, protein, vitamin, mineral dan air) menjadi landasan utamamanusia untuk mencapai kesehatan dan kesejahteraan sepanjang siklus kehidupan.Janin dalam kandungan, bayi, balita, anak, remaja, dewasa maupun usia lanjutmembutuhkan makanan yang sesuai dengan syarat gizi untuk mempertahankanhidup, 
tumbuh dan berkembang, serta mencapai prestasi kerja.

Ketersediaan pangan dapat diwujudkan melalui proses kedaulatan pangan dan penganekaragaman pangan. Pemenuhan kebutuhan pangan merupakan hak negara dan bangsa yang secara mandiri menentukan kebijakan Pangan yang menjamin hak atas Pangan bagi rakyat dan yang memberikan hak bagi masyarakat untuk menentukan sistem pangan yang sesuai dengan potensi sumber daya lokal.

Ketahanan pangan merupakan bagian terpenting dari pemenuhan hak atas pangan sekaligus merupakan salah satu pilar utama hak asasi manusia.Ketahanan pangan juga merupakan bagian yang sangat penting dari ketahanan nasional.Distribusi panganyang tidak merata menjadi kendala untuk mewujudkan ketahanan pangan di tingkat nasional.

Kebijakan ketahanan pangan dalam aspek ketersediaan pangan, difokuskan pada: (a) peningkatan ketersediaan pangan yang beranekaragam berbasis potensi sumberdaya lokal; dan (b) memantapkan penanganan kerawanan pangan untuk mengurangi jumlah penduduk miskin dan kelaparan.

1. Arah kebijakan pemantapan kebijakan ketahanan pangan tersebut dilakukan dengan 5 (lima) strategi utama, meliputi:

Memprioritaskan pembangunan ekonomi berbasis pertanian dan perdesaan untuk:

a) Meningkatkan kapasitas produksi pangan domestik;

b) Menyediakan lapangan kerja; dan

c) Meningkatkan pendapatan masyarakat, Pemenuhan pangan bagi kelompok masyarakat terutama masyarakat miskin kronis dan transien (akibat bencana alam, sosial dan ekonomi) melalui pendistribusian bantuan pangan;

d) Pemberdayaan masyarakat supaya mampu memanfaatkan pangan beragam, bergizi seimbang dan aman (B2SA) berbasis sumber daya lokal;

e) Promosi dan edukasi kepada masyarakat untuk memanfaatkan pangan B2SA berbasis sumber daya lokal;

f) Penanganan keamanan dan mutu pangan segar.

2. Tujuan Implementasi Kebijakan Ketahanan Pangan

Adapun tujuan dari implementasi kebijakan ketahanan pangan menurut (Dewan Ketahanan Pangan 2015 )adalah sebagai berikut :

a) Meningkatkan ketersediaan pangan melalui peningkatan produksi domestik, pengembangan cadangan pangan, pengaturan perdagangan pangan berdasarkan kepentingan nasional, dan pengembangan produksi pangan lokal dan olahan.

b) Memperkuat keterjangkauan pangan, melalui efisiensi fasilitasi pemasaran, sistem logistik pangan, stabilisasi pasokan dan harga pangan, penanganan kerawanan pangan darurat, dan bantuan pangan bagi keluarga miskin.

c) Mengembangkan pemanfaatan pangan, melalui pola promosi konsumsi pangan B2SA, pengembangan diversifikasi konsumsi pangan berbasis pangan lokal, perbaikan gizi masyarakat, dan peningkatan keamanan pangan segar dan olahan.

d) Penguatan kelembagaan pangan dan penguatan koordinasi ketahanan pangan melalui sinergi program dan pelibatan seluruh stakeholders dalam pembangunan pangan dan gizi serta dukungan kebijakan kementerian/ lembaga.

\section{Konsep Kesejahteraan}

Menurut Undang-undang No. 11 Tahun 2009(dalam Sodiq, 2016), tentang Kesejahteraan Masyarakat, kesejahteraan masyarakat adalah kondisi terpenuhinya 
kebutuhan material, spiritual, dan sosial warga negara agar dapat hidup layak dan mampu mengembangkan diri, sehingga dapat melaksanakan fungsi sosialnya.

Menurut Kolle (dalam Rosni, 2017), kesejahteraan dapat diukur dari beberapa aspek kehidupan:

a. Dengan melihat kualitas hidup dari segi materi, seperti kualitasrumah, bahan pagan dan sebagainya;

b. Dengan melihat kualitas hidup dari segi fisik, seperti kesehatan tubuh,lingkungan alam, dan sebagainya;

c. Dengan melihat kualitas hidup dari segi mental, seperti fasilitas pendidikan, lingkungan budaya, dan sebagainya;

d. Dengan melihat kualitas hidup dari segi spiritual, seperti moral, etika, keserasian penyesuaian, dan sebagainya.

Indikator kesejahteraan diatas menjelaskan bahwa untuk mengukurkesejahteraan dilihat dari segi materi, segi fisik, segi mental dan segi spiritual.Dengan demikian bahwa kesejahteraan bukan saja dilihat dari keseluruhan kebutuhan tanpa terganggunya kebituhan yang lain.

\section{METODE PENELITIAN}

Penelitian ini merupakan penelitian kualitatif dengan menggunakan metode deskriptif. tujuannya untuk menggambarkan dan menjelaskan fenomena yang diamati secara langsung dan menghasilkan data deskriptif berupa katakata tertulis berbentuk naratif.(Sugiyono, 2012).

Metode ini diharapkan dapat menejelaskan dan menggambarkan tentang implementasi Kebijakan Ketahanan pangan untuk Meningkatkan Kesejahteraan Masyarakat di Kabupaten Pesisir Selatan. penelitian ini dilakukan di Kabupaten Pesisir Selatan. pemilihan informan, menggunakan teknik purposive sampling yakni pihak-pihak yang memilki infromasi sesuai kebutuhan peneliti, diantarnya Kasubag Perencanaan, Kasi Ketahanan pangan, Wali Nagari dan Masyarakat.
Sumber data yang digunakan dalam penelitian ini menggunakan data primer dan sekunder, yang diambil langsung melalui proses wawancara dan observasi ke lapangan serta dari sumber bacaan dan berita. teknik untuk menguji keabsahann data yang dipakai dalam penelitian ini menggunakan triangulasi sumber, yakni mengecek data yang diperoleh melalui beberapa sumber. kemudian dianalisis dengan cara mereduksi data, penyajian data serta menarik kesimpulan.(Moleong, 2013).

\section{HASIL DAN PEMBAHASAN}

\section{Implementasi Kebijakan Ketahanan pangan untuk Meningkatkan Ketahanan Pangan Masyarakat Kabupaten Pesisir Selatan}

Mengacu oada model implementasi yang dikemukakan oleh Grindel (dalam Header 2008) yang menyaakan bahwa keberhasilan implementasi suatu kebijakan ditentukan oleh dua aspek yaitu isi kebijakan (content of policy) dan lingkungan kebijakan (context of implementation). isi kebijakan tersebut mencakup hal-hal sebagai berikut : kepentingan yang terpengaruh oleh kebijakan, jenis manfaat yang dihasilkan, derajat perubahan yang diinginkan, siapa pelaksana program, dan sumber daya yang dilibatkan. sedangkan lingkungan kebijakan mencakup : kekuasaan, kepentingan dan strategi akator yang terlibat, karakteristik lembaga dan penguasa serta kepatuhan daya tanggap.

a. Aspek Isi Kebijakan

1) Kepentingan kelompok sasaran

Kelompok sasaran dalam kebijakan ketahanan pangan ini adalah masyarakat petani yang tergabung dalam kelompok untuk mengelolaa cadangan pangan mereka sendiri. Kepentingan dari masayrakat ini adalah tercapainya keadilan akan terpenuhi kebutuhan pangan mereka sehari-hari dan terbabas dari kerwanan pangan agar tercapainya kehidupan yang sejahtera bagi masyarakat petani. Masyarakat petani juga akan dilakukan pemberdayaan agar memilki usaha ekonomi produktif yang 
dapat menambah pendapatan anggota kelompok. Usaha ekonomi produktif dilakukan dengan perputaran stok cadangan pangan kelompok itu bisa di jual kepada masyarakat umum yang nantinya keuntungan di bagi sama rata dengan anggota kelompok lain. Kemudian juga sistem tunda jual dimaksudkan apabila saat musim panen raya tiba namum harga gabah turun maka masyarakat dibina untuk menyimpan gabahnya terlebih dahulu di tempat penyimpanan (lumbung) yang pada saat harga gabah naik maka petani bisa menjual dan mendapatkan keuntungan yang lebih besar dari pada menjual gabah pada saat harga gabah turun.

2) Tipe manfaat

Dilihat dari isi kebijakan ketahanan pangan melalaui program pengelolaan cadangan pangan masyarakat dijelaskan bahwa dengan adanya kegiatan ini masyarakat petani mendapatkan bantuan pembangunan fisik tempat penyimpanan (lumbung) pangan yang diperuntukan kepada masyarakat petani agar dapat mengelola cadangan pangan mereka sendiri.Pengelolaan cadangan pangan masyarakat juga di fasilitasi dengan anggaran pengisian untuk mengisi stok cadangan pangan di dalam tempat penyimpanan (lumbung) yang diberikan oleh pemerintah.Pengelolaan cadangan panga masyarakat memilki manfaat unutuk meningkatkan volume cadangan pangan kelompok untuk menjamin akses dan kecukupan pangan bagi anggotanya dan meningkatkan modal kelompok melalui usaha ekonomi produktif di bidang pangan.

3) Derajat perubahan yang diinginkan

Kebijakan ketahanan pangan melalui cadangan pangan masyarakat dikeluarkan ditujukan agar tercapainya keadilan akan kemudahan akses pangan bagi seluruh masyarakat. Dan kebijakan ini juga melakukan pembinaan dan pemebrian sosialisasi kepada masyarakat petani bahwa pada saat harga jual gabah turun sebaiknya dilakukan sistem tunda jual sampai terjadinya peningkatan harga gabah, agar masyarakat petani memilki keuntungan dan tidak dirugikan.

4) Pelaksanaan program

Dilihat dari Undang-Undang tentang pangan pelaksana kebijaka ketahanan pangan pemerintah provinsi menugaskan pemerintah daerah dan mengikut instansi lain dalam pengimplementasian kebijakan ini. Pemerintah Kabupaten Pesisir Selatan menugaskan dan memberikan wewenang kepada Dinas Pangan untuk menjalankan kebijakan dan mengawasi keberlangsungan kebijakan di dalam masyarakat.Pelaksana kebijakan haruslah yang memilki kompetensi, kualitas yang baik serta memahami maksud dan tujuan dari kebijakan ini.

5) Sumber daya yang dilibatkan

Dalam kebijakan ini sumber daya yang dilibatkan adalah pemerintahan nagari yang juga ikut berpartisipasi dalam mengawasi jalannya kebijakan ini di tingkat nagari, kemudian adanya sarana dan prasarana pembangunan tempat penyimpanan (lumbung) yang dibangun oleh pemerintah sebagai tempat penyimpanan stok cadangan pangan bagi masyarakat.Serta partisipasi dari masyarakat petani itu sendiri sebagai kelompok sasaran dalam kebijakan.

\section{b. Aspek Lingkungan}

1) Seberapa besar kekuasaan, kepentingan dan strategi yang dimiliki oleh para aktor yang terlibat dalam implementasi kebijakan

Dinas Pangan memilki strategi untuk mensosialisasikan kagiatan pengelolaan cadangan pangan masyarakat ini dengan mengadakan penyuluhan mengenai kegiatan dan sosialisasi kepada masyarakat petani dan menjelaskan maksud dan tujuan program ini serta member tahu kepada masyarakat bagaimana sistem pengelolaan cadangan pangan masyarakat yang baik agar terjadinya kelancaran program dan keberlanjutan program.

2) Karakteristik lembaga penguasa

Pemerintah daerah sebagai penyelenggara kebijakan di daerah bersama 
dinas pangan berkoordinasi dan bekerja sama dengan pemerintahan nagari dalam mengawasi jalannya kebijakan di dalam masyarakat.

3) Tingkat kepatuhan dan adanya respon dari pelaksana

Dalam implementasi kebijakan ketahanan pangan melalui program pengelolaan cadangan pangan masyarakat, Dinas Pangan sebagai pelaksana yang ditugaskan pemerintah daerah untuk mengawasi kebijakan telah menjalankan dan mematuhi isi-isi dari kebijakan tersebut, Dinas Pangan telah melakukan pendampingan dan memberikan sosialisasi serta telah mengakses anggaran untuk pelaksanaan program tersebut.

\section{Faktor pendukung dan penghambat dalam implementasi kebijakan ketahanan pangan}

a. Faktor pendukung

1. Aspek Isi Kebijakan

a) Kepentingan kelompok sasaran

Ini merupakan salah satu faktor pendukung menurut teori yang di kemukakan oleh Grindel (dalam Haeder 2008) yang mana faktor pendukung dari implementasi dari kebijakan ini adalah adanya anggaran yang disediakan oleh pemerintah untuk pelaksanaan kegiatan, kemudian juga adanya pembangunan tempat penyimpanan (lumbung) yang diperuntukan kepada masyarakat petani dan digunakan sebagai tempat penyimpanan stok cadangan pangan masyarakat.

b) Tipe manfaat

Hal ini sesuai dengan pendapat Grindel (dalam Haeder 2008) bahwa di dalam sebuah kebijakan harus dijelaskan terkait manfaat yang akan diterima kelompok sasaran nantinya, maka faktor pendukung dari tipe manfaat ini adalah disediakan staf pendamping dan penyuluh untuk mengawasi jalannya kebijakan di dalam masyarakat.

c) Derajat perubahan yang diinginkan
Faktor pendukung dalam implementasi kebijakan ketahanan pangan melalui cadangan pangan masyarakat dilihat dari derajat perubahan yang diungkapan oleh Grindel (dalam Haeder 2008) adanya perubahan yang terjadi dalam kehidupan masyarakat, kegiatan pengelolaan cadangan pangan masyarakat ini adalah sebuah kegiatan untuk meningkatkan kesejahteraan masyarakat.

d) Pelaksana program

Berdasarakan (Peraturan Pemerintah No.68 Tahun 2002) pasal 8 tentang ketahanan pangan menjelaskan bahwa masyarakat memilki hak dan kesempatan seluas-luasnya dalam upaya mewujudkan cadangan pangan masyarakat yang dilakukan secara mandiri serta sesuai dengan kemampuan masing-masing, kemudian pada pasal 14 menegaskan bahwa masyarakat memilki kesempatan seluasluasnya dalam mewujudkan ketahanan pangan. dimana peran masyarakat dapat berupa melaksanakan prosuksi, perdagangan, distribusi dan konsumsi pangan kemudian menyelenggarakan cadanganan pangan masyarakat dan melakukan pencegahan dan penanggulangan masalah pangan.
e) Sumber daya yang dilibatkan

Dalam memberikan sosialisasi kepada masyarakat terkait Implementasi kebijakan ketahanan pangan melalui cadangan pangan masyarakat, Dinas Pangan bekerja sama dengan pemerintahan nagari dalam melakukan pengawasan dan pemberian sosialisasi kepada masyarakat petani akan maksud dan tujuan program tersebut

\section{2) Aspek Lingkungan}

a) Seberapa besar kekuasaan, kepentingan dan strategi yang dimiliki oleh para aktor yang terlibat dalam implementasi kebijakan

Pemerintah Daerah mengutus Dinas Pangan menggunakan strategi dengan membetuk staf pendamping dan penyuluh 
dan koordinasi dengan pemerintahan nagari sebagai perpanjangan tangan dari Dinas Pangan untuk mensosialisasikan kebijakan kepada masyarakat yang bertujuan untuk memudahkan pelaksanaan pembinaan dan memfasilitasi sekaligus membina masyarakat petani agar memperkuat kemampuannya dalam penyediaan dan pengelolaan cadangan pangan.

b) Karakteristik lembaga penguasa

Menurut Grindel (dalam Haeder 2008) lingkungan tempat lembaga berada merupakan salah satu faktor pendukung yang mempengaruhi kebijakan.lembaga penguasa kebijakan adalah pemerintah daerah, pemerintahan daerah kemudian menugaskan dan memberikan wewenang kapada Dinas Pangan sebagai lembaga katahanan pangan untuk menjalankan kebijakan

c) Tingkat kepatuhan dan adanya respon dari pelaksana

Sesuai dengan yang dikemukakan oleh Grindel ( dalam Haeder, 2008) bahwa tingkat kepatuhan kelompok sasaran dengan pelaksana juga menjadi salah satu unsur lancarnya suatu kebijakan. Kelompok sasaran kebijakan jika ingin kebijakan berjalan dengan baik dan lancar harus nya mengikuti dan melakukan pengelolaan cadangan pangan dengan sistem yang telah disosialisasikan oleh pelaksana.

b. Faktor Penghambat

1) Aspek Isi Kebijakan

a) Kepentingan kelompok sasaran

Berdasarkan teori model Grindel (dalam Haeder 2008) dilihat dari unsure kepentingan kelompok sasaran yang menjadi faktor penghambat dalam implementasi kebijakan ketahanan pangan malalui pengelolaan cadangan pangan masyarakat adalah kurangnya pengetahuan dan pemahaman anggota kelompok terhadap sistem pengelolaan cadangan pangan yang baik.

b) Tipe manfaat

Pada tipe ini tidak sesuai dengan manfaat yang seharusnya staf pendamping dan penyuluh tidak memberikan pemahaman yang lebih jelas kepada masyarakat yang membuat masyarakat masih belum mengerti bagaiman jalalnya kebijakan tersebut.Hal ini pun mengakibatkan pengelolaan tidak berjalan denga baik dan masyarakat pun belum mandapatkan manfaat dari kebijakan tersebut.

c) Derajat perubahan yang diinginkan

Dalam pengimplementasian kebijakan adanya faktor penghambat seperti masyarakat tidak begitu memahami bagaimana sistem pengelolaan cadangan pangan yang baik dan mengembangkan usaha ekonomi nya.

d) Pelaksanaan program

Dalam pelaksanaan program adanya masalah yang menjadi pengambat dalam implementasi program yaitu keterbatasan SDM yang dimiliiki dan jarak antara instansi pengawas dengan tempat-tempat yang melaksanakan kebijakan berjauahan yang mengakibatkan monitoring ataupun sosialisasi tidak dilakukan secara rutin.

e) Sumber daya yang dilibatkan

Dalam kebijakan ini sumber daya yang menjadi faktor penghambat adalah kekurangan anggaran.Dalam penelitian kelapangan peneiti menemukan keluhan pengurus kelompok bahwasanya anggaran yang diturunkan tidak mencukupi untuk pemenuhan stok cadangan pangan.

2) Aspek Lingkungan

a) Seberapa besar kekuasaan, kepentingan dan strategi yang dimilki oleh para aktor yang terlibat dalam implementasi kebijakan.

Strategi aktor penguasa untuk mengatasi masalah dalam pelaksanaan program dinas pangan telah berupaya memberikan penyuluhan, sosialisasi terhadap masyarakat bahkan pengurus pun telah diberikan pelatihan-pelatihan bagaiaman dapat pengelolaan cadangan pangan dan usahan ekonomi produktif masyarakat tersebut dapat berkembang dan berkelanjutan. 
b) Karakteristik lembaga penguasa

Dinas pangan yang telah diberikan kekuasaan oleh pemerintah derah untuk dapat menjalankan dan mengawasi jalannya kebijakan di dalam masyarakat di anggkap kurang memberikan respon yang cepat terhadap permasalahan yang dikeluhkan oleh anggota kelompok yang mengakibatkan masalah tidak teratasi bahkan berdampak ketidak berkelanjutan program.

c) Tingkat kepatuhan dan adanya respon dari pelaksana

Dinas Pangan selaku pengawas dalam implementasi kebijakan dan anggota kelompok tani selaku pelaksana kebijakan implementasi ketahanan pangan melalui pengelolaan cadangan pangan masyarakat harus menciptakan komunikasi yang baik dan untuk Dinas Pangan sebagai pengawas kebijakan jika ada keluhan-keluhan dari masyarakat harusnya di tanggapi dengan cepat agar permasalah dapat dicarikan jalan keluarnya.

Upaya yang dilakukan untuk mengatasi kendala dalam implementasi kebijakan ketahanan pangan dalam meningkatkan kesejahteraan masyarakat kabupaten pesisir selatan

a. Aspek Isi Kebijakan

1) Kepentingan kelompok sasaran

Adapun upaya yang dilakukan untuk menunjang kelancaran pelaksanaan kebijakan ini adalah dengan memberikan sosialisasi serta penyuluhan kepada kelompok sasaran agar aspek isi kebijakan ketahanan pangan ini dapat berjalan dengan lancar dan kelompok sasaran pun mendapatkan keadilan akan terpenuhinya kebutuhan akan pangan.

2) Tipe manfaat

Dinas Pangan sebagai pengawas kebijakan malakukan upaya untuk memberikan informasi kepada masyarakat terkait akan manfaat dan keuntungan yang akan di dapat dengan adanya kegiatan program pengelolaan cadangan pangan melalui dengan memberikan sosialisai.
3) Derajat perubahan yang diinginkan

Dinas Pangan terus berupaya untu menghidupkan kembali pengelolaan cadangan pangan masyarakat yang tidak aktif lagi dengan berupa memberikan sosialisasi kembali kepada kelompok sasaran dan mencari alternative jalan keluar terhadap permasalahan yang terjadi.

4) Pelaksanaan program

Dalam pelaksanaan kebijakan pastinya ada kendala yang dihadapi diharapkan respon dari lembaga penguasa lebih cepat tanggap dalam menanggapi permasalahan dan keluhan kelompok sasaran.

5) Sumber daya yang dilibatkan

Dinas Pangan mengimbangi pengimplementasian program dengan dibangunnya sebuah tempat penyimpanan (lumbung) yang diperuntukan oleh kelompok sasaran untuk menyimpan hasil panen mereka pada saat harga gabah turun dan sebagai tempat penyimpanan stok cadangan pangan bagi anggota kelompok sasaran.

b. Aspek Lingkungan

1) Seberapa besar kekuasaan, kepentingan dan strategi yang dimilki oleh para kator yang terlibat dalam implementasi kebijakan

Adapun upaya yang dilakukan mengenai permasahan peminjaman gabah/beras pada stok cadangan pangan masyarakat, staf Dinas Pangan turun langsung untuk menemui anggota kelompok yang meminjam agar mengembalikan penjaman sesuai dengan yang telah disepakati sebelumnya secacar bersama-sama dengan angota kelompol lainnya.

2) Karakteristik lembaga penguasa

Untuk kelancaran jalannya kebijakan lembaga penguasa bekerja sama dengan pemerintahan nagari dalam mengawasi pengelolaan cadangan pangan masyarakat. Dan jika ada masalah dalam jalannya kebijakan pemerintahan nagari juga ikut terlibat dalam penyelesaian masalah tersebut. 
3) Tingkat kepatuhan dan adanya respon dari pelaksana

Menurut Grindel ( dalam Haeder, 2008) menyatakan bahwa respon pelaksana diperlukan untuk menilai pelaksanaan dari suatu kebijakan. jika kendala tersebut dapat cepat di atasi dengan baik maka kabijakan akan berjalan dengan baik lagi, dan kebijakan pun akan mengalami perkembangan kea rah yang lebih baik.(Grindel dalam Haeder 2008).

\section{PENUTUP}

Berdasarkan hasil penelitian dan pembahasan yang dilakukan maka dapat diatarik kesimpulan yaitu :

1. Proses Implementasi kebijakan ketahanan pangan melalui pengelolaan cadangan pangan masayarakat di atur dalam (Undang-Undang No 18 tahun 2012 tentang Pangan )yang menyatakan bahwa pemerintah dan pemerintah daerah melaksanakan implementasi kebijakan ketahanan pangan dan bertanggung jawab terhadap penyelenggaraan kebijakan ketahanan di wilayahnya masih-masing dengen memperhatikan pedoman, norma, standard dan kriteria yang ditetapkan pemerintah pusat. Kemudian pemerintah daerah dan pemerintah nagari diikut sertaka sabagai pendorong keiukutsertaan masyarakat dalam penyelenggaraan katahanan pangan.

2. Faktor pendukung dari implementasi kebijakan ketahan panga melalui cadangan pangan masyarakat adalah adanya anggaran yang disediakan untuk pembelian pengisian cadangan pangan anggota kelompok yang kemudian disimpan di tempat penyimpanan (lumbung) yang telah dibangun juga oleh pemerintah melalai dana alokasi Khusus (DAK) bidang pertanian denga dilengkapi lantai jemur dan peralatakan penggilingan gabah. Namun dalam pelaksanaan program ini masih terjadinya permasalah eksternal maupun internal kelompok.
Permalasahan eksternalnya adalah masalah penggunaan lahan untuk pembangunan tempat penyimpanan (lumbung) pangan sedangkan permasalah internalnya adalan anggota kelompok itu sendiri, pengelolaan cadangan pangan masyarakat memang adanya sistem peminjaman gabah/beras pada stok penyimpanan cadangan pangan masyarakat, namun adannya masyarakat yang tidak mengembalikan pinjaman sesuai dengan kesepakatan yang disepakati secara bersama-sama dengan anggota kelompok lain. Bahwasannya gabah/beras yang dipinjam adalah milik bersama anggota kelompok, anggota kelompok lain pu berhak untuk juga meminjam jika terjadinya gagal penen yang membuat anggota kelompok merugi dan susah untuk membeli kebutuhan pangan di pasaran jika terjadinya lonjakan harga kebutuhan akan pangan. Dan adanaya pengelolaan cadangan panan masyaraka yang sudah tidak aktif lagi. Kemudian diperlukan lah upaya yang diharapkan dapat membantu anggota masayrakat kelompok petani agar tetap bisa memenuhi kebutuhan pangan walaupun harga pangan di pasaran terjadi peningkatan harga dan upaya untuk menghidupkan kembali seluruh cadangan pangan masayrakat yang sudah tidak aktif lagi.

3. Upaya yang dilakukan untuk mengatasi permasalah yang timbul dalam implementasi kebijakan ketahanan pangan melalui pengelolaan cadangan pangan masyarakat, baik permasalahan eksternal maupun internal kelompok. Untuk mengatasi masalah eksternal kelompok tentang penggunaan lahan tersebut Dinas Pangan dan pemerintahan nagari berkooridinasi dengan pemilki tanah agar mau menghibahkan tanahnya untuk dibangunya tempat penyimpanan (lumbung) pangan bagi masyarakat, yang pemilik tanah pun merangkap 
Hasanatul Rahmi, JumiatilImplementasi Kebijakan Ketahanan Pangan dalam Meningkatkan Kesejahteraan Masyarakat di Kabupaten Pesisir Selatan (Studi Kasus Pengelolaan Cadangan Pangan Masyarakat)

menjadi ketua pengurus cadanngan pangan masyarakat. Kemudian upaya yang dilakuakn untuk anggota yang meminjam gabah/beras namun tidak dikembalikan Dinas Pangan terjun langsung menenui anggota tersebut untuk mengingatkan bahwa apa yang dipijam dari penyimpanan (lumbung) cadangan pangan harus dikembalikan sesuai dengan kesepakatan yang telah ditentukan bersama-sama. Kemudian upaya yang dilakukan untuk menghidpkan kembali cadangan pangan masyarakat dinas pangan berpaya unuk kembali memberikan sosialisasi dan penyuluhan kepada kelompok cadangan pangan masyarakat yang sudah tidak aktif lagi agar cadangan pangan kelompoknya kembali diaktifkan.

\section{DAFTAR KEPUSTAKAAN}

Akib, H., \& Tarigan, A. (2008). Artikulasi Konsep Implementasi Kebijakan. Jurnal Baca, Vol. 1 A.

Dewan Ketahanan Pangan 2015. (n.d.). Kebijakan Strategis Pangan dan Gizi 2015-2019.

Moleong, L. (2013). Metode Penelitian Kualitatif (EdisiRevisi). Bandung: PT. Remaja Rosda karya.

Pemerintah Republik Indonesia. (2012). Undang-Undang Republik Indonesia Nomor 18 Tahun 2012 (pp. 1-25). pp. $1-25$.
Peraturan Pemerintah Republik Indonesia. (2002). Peraturan Pemerintah Republik Indonesia Nomor 68 tahun 2002 Tentang Ketahanan Pangan. (57).

Rosni, R. (2017). Analisis Tingkat Kesejahteraan Masyarakat Nelayan Di Desa Dahari Selebar Kecamatan Talawi Kabupaten Batubara. Jurnal Geografi, 9(1), 53.

Sodiq, A. (2016). Konsep Kesejahteraan Dalam Islam. Equilibrium, 3(2), 380405.

Sugiyono. (2012). Metode Penelitian Kuantitatif, Kualitatif, dan $R \& D$. Bandung: Alfabeta.

Supriyanto, T. (2014). Analisis Tingkat Ketahanan Pangan Rumah Tangga Tani Desa Mandiri Pangan Di Kecamatan Karanggede Kabupaten Boyolali. Surakarta: Fakultas Ekonomi dan Bisnis Universitas Sebelas Maret.

Suryati. (2014). Implementasi Kebijakan Ketahanan Pangan Daerah (Studi pada program peningkatan produksi beras nasional 9P2BN Kabupaten Kota Waringin Barat). Program Pasca Sarjana Universitas Terbuka.

Wahab, S. A. (2014). Analisis Kebijakan dari Formulasi ke Penyusunan ModelModel Implementasi Kebijakan. Jakarta: Bumi Aksara. 